\title{
Cloning debates
}

\section{Crafting a Cloning Policy: From Dolly to Stem Cells By Andrea L. Bonnicksen}

Georgetown University Press, \$39.95 (cloth), ISBN 0-87840-370-1, 2002

\section{Reviewed by R. Alta Charo}

Associate Dean for Research and Faculty Development, University of Wisconsin Law School, and Professor of Law and Bioethics, University of Wisconsin Law and Medical Schools, Madison, Wisconsin, USA.

Whereas human cloning has been debated by politicians and ethicists largely in terms of its effects on society, children and our sense of personal identity, its deeper challenges lie in the realm of abortion politics and our understanding of reproductive liberties. This is not because cloning represents a new and desirable reproductive option; only a handful of citizens and academics seriously promote its use for making children. Instead, cloning has been a wedge issue, and opponents of abortion rights have taken advantage of its alarming imagery to attempt, once again, to halt embryo research in the United States and gain a congressional statement that protection of embryos is more important than women's rights.

Andrea Bonnicksen, a well known and prolific academic bioethicist, has produced a highly readable, detailed, well researched and well organized treatment of the cloning debate in the United States and abroad. Her book, Crafting a Cloning Policy, chronicles the public policy debates and public commissions

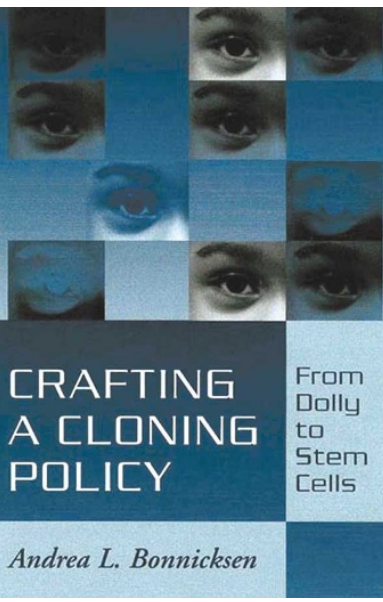

She concludes her book with a cogent outline of various options available to policymakers, including their strengths and weaknesses. These options include drafting new legislation particular to cloning amending existing regulatory mechanisms to strengthen governmental oversight and relying completely on existing mechanisms. Unlike other commentators on this topic, Bonnicksen explores at some length the myriad ways in which current law and regulations already protect society from the most abusive cloning: the premature experimentation with human reproductive applications that would put offspring at significant risk of serious physical deficits. Throughout the book, there is a refreshing absence of hysteria and ideological bias. In addition, Bonnicksen pays close attention to the mundane but crucial details of existing regulatory authority lodged within the Food and Drug Administration.

But no book can possibly capture all the facets of this debate. Missing from this volume is the that have concerned themselves with human cloning, and gives substantial attention to the interplay between government policy on cloning and government policy on reproductive technologies in general.

Bonnicksen uses the debates over human embryonic stem cells to describe the post-2000 congressional debates over reproductive cloning and cloning designed to make embryos for the purpose of retrieving stem cells for specialized medical research and experimental therapies. She also acknowledges the tortured history of efforts to create government bodies to directly regulate reproductive and genetic technologies against the backdrop of abortion politics. This history sets the United States apart from other countries, such as Britain, that have successfully created such regulatory bodies and achieved some degree of public acquiescence to governmental policy. more fluid and subjective swirl of the politics of abortion and genetics that underlie the motivations of the activists and politicians whom the author chronicles. Within the world of 'genetics skeptics', for example, frustration with a US policy that presumes the safety of genetically modified organisms until they are proven dangerous (in contrast with the precautionary approach taken in Europe) led some to see cloning as a welcome opportunity to galvanize action against at least one new technology. Those in the anti-abortion movement are frustrated that years of legislative action at the state level to introduce obstacles - such as parental consent and notice laws, waiting periods, clinic facility regulations and so on-have yet to produce a dramatic cultural aversion to abortion, and that their attempts to have the Supreme Court reverse its 1973 decision Roe vs. Wade have failed. They have thus leapt into the cloning battle, with substantial lobbying of Congress, to use this as a vehicle to go beyond the prohibition of federal funding of embryo research to criminalize even privately funded research at purely private facilities. The women's movement has remained cautious, fearful that condemnation of even reproductive applications of cloning might weaken its rights-based approach to abortion, in which arguments are premised on a largely unfettered right of individuals to engage in sexual and reproductive behaviors without governmental limitation. And academic bioethicists, most of whom lack governmental experience, have proposed idealized governmental bodies to guide and control all reproductive and genetic technologies, with seemingly little regard for the paralyzing effect of abortion politics on such bodies in the past.

Though Bonnicksen's book carefully documents the late 1990s congressional efforts to ban reproductive cloning, it fails to document equally well the degree to which such efforts were derailed by abortion opponents, who padded proposed legislation with amendments to halt embryo research as well. And, owing to production schedules, the book misses the 2002 congressional debates, in which efforts to halt reproductive cloning were once again tied to prohibitions of certain forms of stem-cell research in an effort to court key support with the anti-abortion movement. This was an important goal for the G.W. Bush administration, after its 2001 pronouncement of limited federal funding for some forms of stem-cell research disappointed many key anti-abortion constituency groups, and for many senators who were facing midterm elections that would decide which party would control the Senate. It was not just extensive lobbying by patients, scientists and women's groups that kept prohibitory legislation from being passed; the decisive factor was the Democratic leadership of the US Senate. Last month's change in the US Senate to Republican leadership paves the way for re-introducing such bills, just in time for the 2004 election cycle to frighten pro-research congressmen and senators into silence.

For those who have not followed the cloning debate in detail, and who wish to understand the options and legal pitfalls before us, Crafting a Cloning Policy is a marvelously detailed and readable chronicle. For those who wish to become active in the debate, it is essential reading on the basics of the history and parameters of the controversy, which could help readers to better appreciate the full flavor of the political motivations that lie beneath the public statements. 